\title{
A Systematic Review and Meta-analysis of Alcohol Use Disorders and Its determinants in People Living with HIV in Africa: A Continent based Review and Meta-analysis study.
}

\author{
Mogesie Necho ( $\square$ nechomoges2014@gmail.com ) \\ Wollo university https://orcid.org/0000-0003-0961-7835 \\ Asmare Belete \\ wollo university \\ Yibeltal Getachew \\ wollo university
}

\section{Research}

Keywords: Meta-analysis, alcohol use disorder, AIDS, Africa

Posted Date: April 28th, 2020

DOI: https://doi.org/10.21203/rs.3.rs-22440/v1

License: (c) (1) This work is licensed under a Creative Commons Attribution 4.0 International License. Read Full License

Version of Record: A version of this preprint was published on August 24th, 2020. See the published version at https://doi.org/10.1186/s13011-020-00301-6. 


\section{Abstract \\ Background}

Alcohol use disorder among people living with HIV/AIDS contributes to decreased adherence and effectiveness of antiretroviral medication, decreased help-seeking to HIV/AIDS care and treatment, increased load of the virus in the blood, and development of drug-resistant HIV strains. This study therefore aimed and assessed the pooled evidence on prevalence and associated factors of alcohol use disorder in retroviral infected patients in Africa.

\section{Methods}

We implemented our electronic data base search on PubMed, Scopus, EMBASE, and Psych-INFO libraries. In addition, WHO websites and Google scholar were also investigated for grey literatures. Moreover, we further investigated the reference lists of published articles. Stata-11 meta-prop package with $95 \%$ confidence interval was used. Subgroup and sensitivity analysis were also performed. Cochran's Q- and the $\mathrm{I}^{2}$ test were used to check heterogeneity. Publication bias was evaluated with Egger's test and funnel plots.

\section{Results}

In this meta-analysis, we included 22 studies with a total of 16774 patients and the pooled prevalence of alcohol use disorder was $22.03 \%$ ( $95 \% \mathrm{Cl}: 17.18,28.67)$. The average prevalence of AUD in South Africa (28.77\%) was higher than in Uganda (16.61\%) and Nigeria (22.8\%). Besides, the average prevalence of AUD in studies published before $2011,2011-2015$, and after 2015 was found to be $13.47 \%, 24.93 \%$ and $22.88 \%$ respectively. Moreover, the pooled magnitude of AUD among studies which utilized a sample size $>450$ was $16.71 \%$ whereas it was $26.46 \%$ among studies that utilized sample size $<450$. Furthermore, the pooled estimated prevalence of hazardous, harmful and dependent drinking was $10.87 \%, 8.1 \%$, and $3.12 \%$ respectively. Being male was an associated factor for alcohol use disorder (AOR $=5.5 \% ; 95 \% \mathrm{Cl}$ : $1.10,9.98)$. Moreover, the average odds ratio of cigarette smoking and chat chewing were found to be $3.95 \%(95 \% \mathrm{Cl}: 3.00,4.89)$ and $3.34 \%(95 \% \mathrm{Cl}: 1.71,4.96)$ respectively.

\section{Conclusion}

The average estimated prevalence of AUD in HIV/AIDs patients was high and factors such as being Male, cigarette smoking and chat chewing were associated with it. Early detection and appropriate management of AUD and the mentioned associated factors have to be a routine practice.

\section{Background}


Alcohol can be defined as a psychoactive drug which is the capable of producing physiological as well as psychological dependence and its Harmful use is associated with tremendous health, social and economic consequences(1-3). Alcohol use disorders (AUDs) contribute to $3.8 \%$ of the burden of disease globally(4) The global burden of deaths due to alcohol outweighs the synergized burden of deaths from acquired immunodeficiency syndrome (AIDS), human immunodeficiency virus (HIV), tuberculosis and violence(3). AUDs can be of harmful use, hazardous or dependence use(5). Harmful alcohol use is a pattern of use in control of the will of individual, Hazardous use which has risk of harmful social, physical and mental consequences and dependence is the most severe end of the AUD spectrum $(4,5)$.

The magnitude of alcohol use disorders in patients with retroviral infection has been evidenced higher than people without retroviral infection or the general public (6). A systematic review and meta-analysis study by Duko et al.2019(7) showed that the average worldwide prevalence of alcohol use disorder among patients with HIV/AIDS was found to be $29.8 \%$. Earlier studies reported that the prevalence of alcohol use disorder ranges from $17-39.4 \%$ in Nigeria (8-10) $1.4-33 \%$ in Uganda(11-14), $6.6-48.5 \%$ in south Africa (15-18), 5.4-33\% in Kenya(19-22), and 14.8\% in Zambia (23). There Exists a scarcity of data on alcohol use disorders in people with HIV in other African countries despite the high disease burden with many people living with $\operatorname{HIV}(24)$.

In Ethiopia studies conducted so far implied that AUD among HIV/AIDS patients was documented to be $32.6 \%$ in Jimma university specialized hospital (25), and 31.8\% in Hawassa university comprehensive hospital(26), 14.2\% in Bishoftu general hospital (27), 24.8\% in Assela teaching hospital (28). Moreover, a systematic review and meta-analysis study of alcohol consumption in Ethiopia by Ayano et al.2019(29) reported that the prevalence of hazardous alcohol consumption was $8.96 \%$.

Factors found to be associated with AUDs in these settings include male gender, psychological morbidity, smoking cigarettes, Christian religion, lower education, peer pressure, parental modeling and drinking in order to assist social interactions $(9,10,30-32)$. Studies from Ethiopia also concluded that being male, smoking cigarettes and psychological distress were determinants of AUDs (25).Another study also reported that being male, poor social support, medication non-adherence, khat chewing and cigarette smoking had significant association with alcohol use disorder (26).

AUDs among PLHIV contributes to premature death $(33,34)$ due to enhancement of the toxicity of antiretroviral treatment (ART), damage to liver from concurrent infection, decreased adherence and effectiveness of antiretroviral medication leading to rising opportunistic diseases due to immunecompromization (35-39). Other studies also concluded AUD have been linked with adherence problem to ART drugs (3, 40-43), decreased help-seeking to HIV/AIDS care and treatment facilities(44), increased load of the virus $(39,42)$, with rapid decline of CD4 cells as well as fast HIV/AIDS disease progress and development of drug-resistant HIV strains $(3,39,42)$. Besides, AUD contributes to risky sexual and nonsexual behaviors $(34,45-47)$. A study in USA approved that if an individual with HIV virus consumes alcohol once/week his life span will be shortened by two years and by 6.5 years if consumes alcohol 
daily (48). In addition, such patients with AUD might afraid of interaction between ART drugs and alcohol so that, skipping ART drugs during alcohol intake $(9,40)$.

Despite the fact that multiple studies have been performed and showed that retroviral infected patients have higher prevalence of alcohol use disorder than the general population, to date no published study in Africa per investigators knowledge reported the pooled prevalence and associated factors of alcohol use disorders in human immune-deficiency virus infected patients. Knowledge on pooled magnitude of alcohol use disorders and detecting its determinants would assist policy-makers and program implementers in deciding evidence-driven prevention and promotion and treatment activities in this area.

So, this systematic review and meta-analysis study is intended to review the existing pieces of evidences on alcohol use disorder and its risk factors and pooling them to have a synergized effect in human immune-deficiency virus infected patients in Africa.

\section{Methods}

This Preferred Reporting Items for Systematic Reviews and Meta-analysis Protocols (PRISMA-P) 2015 (49) had been used as an important guideline during the current study.

\section{Data sources and search strategies}

We conducted our search in the following libraries; EMBASE, Psych-Info and Scopus and PubMed with a systematic search approach. We conducted our search in PubMed with the following key terms and words: (Prevalence OR epidemiology OR magnitude OR incidence) AND (Alcohol use disorder OR alcohol abuse OR alcohol use) AND (HIV OR human immunodeficiency virus OR AIDS OR PLWHA OR ART) AND (factor OR risk OR risk factor OR determinant) AND (Southern Africa OR Central Africa OR East Africa OR North Africa OR Western Africa OR Sub-Saharan Africa). Besides, we thoroughly investigated WHO websites and Google scholar for non-published works. Moreover, the lists of references for an included study were searched adequately to further include unaddressed eligible literatures. For further clarification of unclear ideas, we contacted authors of included articles.

\section{Inclusion criteria}

All cross-sectional, case control and cohort studies which had reported the magnitude of alcohol use disorders and/or its determinants among human immune-deficiency virus infected patients in Africa were included. A research article was eligible for inclusion if:

- The study was of cross sectional, cohort and case control study.

- The study population were people living with HIV/AIDS

- Publication of the article should be purely in English language

- The research article had reported prevalence of alcohol use disorder in PLWHIV

- The research articles had identified risk factors of alcohol use disorders in PLWHIV 
- The research article should have generated evidence for the specified target population in African countries.

\section{Exclusion criteria}

- We excluded letters, reviews, interventional studies, commentaries and editorials

- Studies duplicated were also excluded to avoid being doubled in the analysis

\section{Selection of studies for inclusion in the review}

Articles retrieved from the search databases were stored, managed and used in an EndNote reference manager. Two review authors ( $M N, A B)$ reviewed each studies title and abstracts stored in an EndNote reference manager independently and any disagreements between them whether to include or exclude the study for analysis was solved through discussion with the third author (YG).

\section{Data extraction and management techniques}

Using a standardized data extraction form, three authors ( $M N, A B$ and $Y G$ ) extracted data from included studies independently. The following elements were components of the data extraction form. First author last name, year of publication, study setting, sample size, number of events, data on prevalence of alcohol use disorder, tool used for assessment, associated factors, and odds ratio (OR) with $95 \%$ confidence intervals (Cl).

\section{Quality assessment methods}

Two review authors ( $\mathrm{MN}$ and $\mathrm{AB}$ ) assessed the quality of all included studies independently.

Discrepancies between these review authors were fixed by a third reviewer (MN). The modified version of Newcastle-Ottawa Quality Assessment tool (50) was used as guide line for quality appraisal of included studies. Representativeness and size of sample, comparability between study subjects, ascertainment of alcohol use disorder symptoms, and statistical quality were the dimensions of Newcastle-Ottawa scale in assessing the quality of each study.

\section{Data synthesis and analysis}

The pooled magnitude of alcohol use disorder and the pooled odds ratios (OR) of identified risk factors for alcohol use disorders with $95 \% \mathrm{Cl}$ were calculated through random-effects(51) and quality-effects models(52). Heterogeneity between the studies was investigated with both Cochrane's Q statistic and the 12 statistics. 12 value greater than $50 \%$ will be classified as implication of substantial heterogeneity between studies(53).

Subgroup analyses and sensitivity analysis were also performed to explore the sources of heterogeneity. All statistical analyses had been performed using Meta-XL version 5.3(54) and STATA11 Meta-prop package(55). Publication bias was assessed with funnel plot (56) and eggers regression test.

\section{Results}




\section{Identification of studies}

A total of 1357 articles were identified in our electronic search of the specified data bases. Furthermore, a manual search for the reference lists other articles also resulted in 5 additional articles. This makes the overall search result to be 1362 articles. Of these 28 were duplicates and so removed. After a detailed screening of the remaining articles, only 62 articles were reviewed their full text for eligibility. Finally, only twenty two articles were included in the analysis by fulfilling our pre-specified inclusion criteria (Fig. 1)

\section{Characteristics of included studies}

A total of 22 studies in Africa continent that investigated alcohol use disorder in 16774 patients who were on anti-retroviral therapy in Africa have been integrated into this systematic review and meta-analysis study $(7-23,27,28,57-60)$. Considering the type of study design, 18 studies were cross-sectional type and the other four studies $(11,17,21,22)$ were cohort in design. Among the 22 studies in the metaanalysis $(7-23,27,28,57-60), 5$ were from Ethiopia $(7,27,28,57,59), 3$ were from Nigeria (8-10), 4 were from Uganda (11-14), another 4 were form south Africa (15-18) and the remaining 6 studies were from Kenya, Namibia and Zambia $(19-23,60)$. Besides, of all included studies, three were published before $2011(9,12,15)$, eight were published $b / n$ 2011-2015 $(10,13,14,19,21-23,59)$, and the remaining eleven were published after $2015(7,8,11,17,18,20,27,28,57,58,60)$. Moreover, considering the sample size utilized in the study, 10 studies $(8,13-15,18,21-23,27,60)$ assessed $>450$ participants and the remaining 12 studies $(7,9-12,16,17,19,20,28,57,59)$ takes a sample of $<450$ participants(Table 1 )

\section{Quality Of Included Studies}

In general, the summary quality assessment result of 22 included studies integrated in the current metaanalysis ranges from 7 to 10 according to the scoring system of Newcastle Ottawa quality assessment. Amongst the 22 included studies, 19 were found to have good quality and the remaining 3 were having moderate quality. However, there was no study found to have poor quality (Additional file 1)

\section{The pooled prevalence of alcohol use disorder among HIV/AIDS patients who were on anti-retroviral therapy in Africa}

Twenty two studies had been included in the final meta-analysis to determine the pooled magnitude of alcohol use disorder among patients on anti-retroviral therapy in Africa (7-23, 27, 28, 57-60). The reported magnitude of alcohol use disorders among studies included in the current review and metaanalysis ranges from as low as $1.4 \%$ in Uganda (12) to as high as $48.5 \%$ in south Africa(16). The average prevalence of alcohol use disorder among patients on anti-retroviral therapy in Africa using the random effect model was $22.03 \%$ ( $95 \% \mathrm{Cl}: 17.18,28.67)$. This average prevalence has been influenced by a 
significant heterogeneity $\left(I^{2}=99.8 \%, p\right.$-value $\left.=0.000\right)$ from the difference between the incorporated studies (Fig. 2).

\section{The pooled prevalence of hazardous alcohol use among HIV/AIDS patients who are on anti-retroviral therapy in Africa}

Among the 22 studies included in the final analysis, Data regarding hazardous drinking was described in seven studies $(8,10,19,22,27,57,59)$. The aggregate prevalence of hazardous drinking in these studies was $10.87 \%(95 \% \mathrm{Cl}: 4.82,16.93)$. This average result was with considerable heterogeneity $\left(\mathrm{I}^{2}=99.6 \%, \mathrm{P}\right.$ $=0.00)($ Fig. 3). The pooled prevalence of hazardous drinking was $10.87 \%(95 \% \mathrm{Cl}$ : $0.89,20.47)$ in studies that utilized a sample of $>400(8,22,27,59)$, and $11.15 \%(95 \% \mathrm{Cl}: 10.40,11.90)$ in studies that used smaller sample $(10,19,57)$.

\section{The pooled prevalence of harmful alcohol use among HIV/AIDS patients on anti-retroviral therapy in Africa}

Seven studies had reported the information regarding prevalence of harmful drinking in HIV/AIDS patients $(8,10,19,22,27,57,59)$. The pooled prevalence of harmful drinking among the indicated studies was obtained to be $8.1 \%(95 \% \mathrm{Cl}: 1.04,15.17)$ and was having a significant heterogeneity $\left(\mathrm{I}^{2}=99.5 \%, \mathrm{P}=\right.$ 0.00 ) (Fig. 4). Consequently, we performed a subgroup of harmful drinking based on sample size used. The Prevalence of harmful drinking among studies that used relatively larger sample $(>400)(8,22,27$, 59) was found to be 4.08 (95\% Cl: $1.14,7.02)$ whereas it was $13.47 \%(-2.97,29.91)$ in studies which used sample size $<400(10,19,57)$.

\section{The pooled prevalence of dependent drinking among HIV/AIDS patients who are on anti-retroviral therapy in Africa}

Moreover, the 7 studies $(8,10,19,22,27,57,59)$ also illustrated information concerning dependent drinking among HIV/AIDS patients on anti-retroviral therapy. The average magnitude of dependent drinking was obtained to be $3.12 \%(95 \% \mathrm{Cl}: 1.45,6.70)$ and an obvious heterogeneity has also been detected in the result $\left(\mathrm{I}^{2}=99.6 \%, \mathrm{P}=0.00\right)$ (Fig. 5). The average magnitude of dependent drinking among studies that utilized sample of more than $400(8,18,22,27,59)$ was $1.76 \%(1.16,3.68)$ whereas it was $6.56 \%$ (95\% Cl: $2.51,17.64)$ among smaller sample studies $(19,57)$. 


\section{Subgroup analysis of the prevalence of alcohol use disorders among HIV/AIDS patients on ART therapy in Africa}

Since the pooled prevalence of alcohol use disorder was influenced by a significant heterogeneity, a subgroup analysis has been implemented based on country where the study was conducted. Based on this among the 22 studies integrated in the meta-analysis $(7-23,27,28,57-60), 5$ were from Ethiopia ( 7 , $27,28,57,59), 3$ were from Nigeria (8-10), 4 were from Uganda(11-14), another 4 were form south Africa (15-18) and the remaining 6 studies were from Kenya, Namibia and Zambia $(19-23,60)$.

The average prevalence of alcohol use disorder among patients on ART in Ethiopia was $23.36 \%$ (95\% Cl: $17.53,31.19)$ with $\left(I^{2=} 98.6 \%, \mathrm{p}\right.$-value < 0.001$)$. The pooled prevalence of AUD in South Africa was also found to be $28.77 \%(95 \% \mathrm{Cl}$ : $10.39,47.16)$ with $\left(\mathrm{I}^{2}=99.2 \%, \mathrm{p}<0.001\right)$. Besides, the average magnitude of AUD in Uganda and Nigeria were $16.61 \%$ (95\% Cl: $6.86,26.36)\left(\mathrm{I}^{2}=99.8 \%, \mathrm{p}<0.001\right)$ and $22.8 \%(95 \% \mathrm{Cl}$ : $6.83,38.77)\left(I^{2}=99.5 \%, p<0.001\right)$ respectively.

Besides, the average prevalence of AUD in studies which were published before $2011(9,12,15), 2011-$ $2015(10,13,14,19,21-23,59)$, and after $2015(7,8,11,17,18,20,27,28,57,58,60)$ was found to be 13.47\% (95\% Cl: 0.20, 26.75), 24.93\% (95\% Cl: 15.10,34.77) and $22.88 \%(95 \% \mathrm{Cl}: 17.71,28.25)$ respectively. Moreover, the average magnitude of AUD among studies which utilized a sample size $>450$ $(8,13-15,18,21-23,27,60)$ was obtained to be $16.71 \%(95 \%$ Cl: $10.30,23.12)\left(I^{2}=98.5 \%, p\right.$-value < $0.001)$ whereas it was found to be $26.46 \%(95 \% \mathrm{Cl}: 20.21,32.72)\left(\mathrm{I}^{2}=99.20 \%\right.$, p-value $\left.<0.001\right)$ among studies that utilized sample size $<450(7,9-12,16,17,19,20,28,57,59)$ (Table 2).

\section{Sensitivity analysis}

To detect further the source of heterogeneity that influences the average prevalence of AUD in patients, we also investigate a one study leave out at a time sensitivity analysis. The result from the sensitivity analysis revealed that the average estimated magnitude of AUD obtained when each individual study were left out from analysis was with in the $95 \%$ confidence interval of average alcohol use disorder when all studies were pooled together. Therefore, the result of the average magnitude of AUD in HIV patients can be plausible. Moreover, the one study leave out at a time sensitivity analysis result revealed that the average AUD prevalence ranges between $20.77(95 \% \mathrm{Cl}: 16.33,25.31)$ and $22.98 \%(95 \% \mathrm{Cl}: 18.05,27.91)$ when each individual studies were excluded (Table 3).

\section{Publication bias}

We carried out an egger's publication bias plot to detect the presence of a publication bias but it is near the origin and the result of eggers publication bias plot had insignificant $p$-value $(P=0.22)$ on condition that no substantial publication bias for the prevalence AUD in Africa. Moreover, a visual inspection from a funnel plot for a Logit event rate of prevalence of AUD in HIV AIDS patients against its standard error suggests an additional evidence for the absence of a small study effect (Fig. 6). 


\section{Narrative description of the associated factors for Alcohol use disorders}

Of 22 included studies, 12 studies that reported associated factors for alcohol use disorder among HIV AIDS patients were included in our narrative analysis $(8-10,16,17,20,21,27,28,57,59,61)$ (Table 4). Seven of the included studies $(7,9,10,16,28,57,59)$ reported an association between being male and alcohol use disorder. Cigarette smoking was also reported as a related factor for AUD in four $(7,27,57$, $59)$ studies. Furthermore, family history of alcohol use $(27,28)$, missing ART medication(21, 27), mental distress(59), chat chewing $(7,27,57)$, educational status(10, 27), low CD 4 count(57), low income(10), orthodox religion(59), protestant religion(59) had a strong and significant association with alcohol use disorder in people with HIV AIDS in Africa.

\section{The association between male sex and alcohol use disorder in HIV/AIDS patients on ART therapy}

Information concerning the association of being male and higher risk of alcohol use disorder in HIV/AIDS patients was reported in seven of the included studies $(7,9,10,16,28,57,59)$. The average adjusted odds ratio of increased risk of having alcohol use disorder was $5.5(95 \% \mathrm{Cl}: 1.10,9.98)\left(I^{2}=90 \%, P<0.01\right)$. This implied that male HIV/AIDS patients who were on ART were 5.5 times at higher risk of having alcohol use disorder as compared to female patients who were on ART therapy.

\section{The association between cigarette smoking and chat chewing with alcohol use disorder}

Among the 22 studies incorporated in the current meta-analysis $(7-23,27,28,57-60)$, four $(7,27,57,59)$ had reported cigarette smoking as an independent factor for alcohol use disorder in HIV patients. The average odds ratio of cigarette smoking in these studies was found to be $3.95 \%(95 \% \mathrm{Cl}: 3.00,4.89)\left(\mathrm{I}^{2}=\right.$ $96.2 \%, \mathrm{P}<0.01)$. This result suggested that patient's on ART who were smoking a cigarette were on average 4 times at increased risk of developing alcohol use disorder than patients who were not smoking cigarette. Similarly, three of the above indicated studies $(7,27,57)$ had also reported chat chewing as a risk factor for alcohol use disorder. The average odds ratio of chat chewing among these studies was found to be $3.34 \%(95 \% \mathrm{Cl}: 1.71,4.96)\left(I^{2}=98.2 \%, \mathrm{P}<0.01\right)$. Therefore, patients who were chewing chat were on average 3.3 times more likely to have alcohol use disorder than patients who were not chewing chat.

\section{Discussion}

To date as per the knowledge of investigators, this review and meta-analysis on the magnitude of alcohol use disorders and its associated factors in patients who are on anti-retroviral therapy is the first of its kind in Africa. This study from its beginning aimed and assessed the prevalence of alcohol us disorder and its associated factors in African population. Consequently, the information generated from this meta- 
analysis on average magnitude and associated factors for alcohol use disorder in HIV/AIDS patients would be significant evidence to diverse stakeholders planning to design strategy in the area.

Twenty two studies that assessed AUD in HIV patients in Africa were incorporated in the final analysis. The average prevalence of alcohol use disorder in the current meta-analysis was high $22.03 \%$ higher than the pooled prevalence of hazardous alcohol use in the general population(29). This high magnitude in such vulnerable population publicized AUD as an important community health problem.

The prevalence of AUD in this study was lower as compared to the result of a systematic review and meta-analysis study by Duko et al.2019(7) in which that the average worldwide prevalence of AUD among patients with HIV/AIDS was found to be $29.8 \%$. This could be due to the disparities in the principal economic, social and cultural factors in which alcohol use behaviors are favorably higher in developed countries than African countries.

This pooled prevalence of AUD in our study was considerably higher in South Africa (28.8\%) than the pooled prevalence estimate in Uganda (16.6\%). South Africa is a relatively economically advanced nation than Uganda so individuals would have ability to afford alcohol.

As expected, the pooled estimated prevalence of AUD in studies that studied a relatively higher sample (> 450) was significantly lower (16.7\%) than pooled estimated prevalence for studies which assessed smaller sample $(<450)$ which was $26.5 \%$. This could be due to the decreases in the probability of a standard error when using larger sample size and so providing a more precise and reliable result with strong power.

In addition, pooled estimated prevalence of AUD was higher among studies done in 2011 and after (22.9-24.9\%) than pooled estimate of AUD in studies which were done before 2011(13.5\%). The increased availability of alcohol and alcohol advertising programs at current times could bring such variation.

The pooled estimated magnitude of hazardous alcohol use, harmful alcohol use and dependent drinking in this study was found to be $10.87 \%, 8.1 \%$, and $3.12 \%$ respectively. The pooled estimated prevalence of AUD was $4 \%$ in studies that used larger sample size $(>400)$ and is lower than the pooled estimated prevalence in studies that assessed relatively smaller sample size $(<400)(13.5 \%)$. Furthermore, the pooled estimated prevalence of dependent drinking was also higher in smaller sample studies $(6.7 \%)$ than larger sample studies (1.8\%).

Concerning the associated factors for AUD, being male $(7,9,10,16,28,57,59)$, Cigarette smoking $(7,27$, $57,59)$, family history of alcohol use(27, 28), missing ART medication(21, 27), mental distress(59), chat chewing $(7,27,57)$, educational status $(10,27)$, low CD4 count(57), low income(10), orthodox religion(59), protestant religion(59) had a strong and significant association with AUD in people with HIV AIDS in Africa. 
Association between male sex and alcohol use disorder was identified in this study. The pooled estimated odds ratio of being male as risk factor for AUD was 5.5 in this study. This showed that male patients with HIV were 5, 5 times more vulnerable to develop AUD than female patients. Supportive evidence for this existed in a meta-analysis study(7). Factors related to variation in neurochemistry could be responsible for this. This can be illustrated by a US study that revealed that higher rate of dopamine release was observed in men than women despite the same level of alcohol intake(62) that can further reinforce the alcohol seeking behavior and heighten the risk of AUD. Besides, some culture restrict alcohol consumption in women which could further reduce the risk of AUD in women and also other factors in the environment may have additive role for the difference(63).

The pooled estimated odds ratio of cigarette smoking and chat chewing in this study were 3.9 and 3.3.Patients who were smoking cigarette and chewing chat were nearly 4 times and 3.3 times more likely to develop AUD than patients who were not smoking cigarette and chewing chat. These substances have similar mechanism of action with alcohol(64) and therefore one can potentiate the rewarding effect of the other(65).

\section{Difference between studies incorporated in the current review and meta-analysis study}

This meta-analysis study on prevalence of AUD and its related factors in HIV AIDS patients in Africa had a significant heterogeneity from the variance between the incorporated studies. Therefore we further perform a sub-group analysis to explore the source of such substantial heterogeneity. The subgroup analysis revealed that the setting at which the study was done, and the sample size variation between the studies and study period were responsible for the variance in prevalence of alcohol use disorder between included studies. On top of this we conducted a one study leave out sensitivity analysis but the result showed that the overall pooled estimated prevalence of AUD was not under the influence of a single particular study. This meta-analysis study on AUD has limitations to be considered in using its result. The primary limitation is that it was under the influence of a significant heterogeneity. Furthermore, at some sub-groups we integrate few numbers of studies so that the precision of estimate might be affected.

\section{Conclusion}

This review and meta-analysis study found a high pooled magnitude of AUD in African population living with HIV; nearly one in five (22\%). This average estimated prevalence of AUD substantial heterogeneity. This pooled prevalence of AUD was considerably higher in South Africa (28.8\%) than the pooled prevalence estimate in Uganda (16.6\%). Besides, the pooled estimated prevalence of AUD in studies that studied a relatively higher sample ( $>450)$ was significantly lower $(16.7 \%)$ than pooled estimated prevalence for studies which assessed smaller sample $(<450)$ which was $26.5 \%$. In this study the pooled estimated magnitude of hazardous alcohol use, harmful alcohol use and dependent drinking were also $10.87 \%, 8.1 \%$, and $3.12 \%$ respectively. Factors such as being male, Cigarette smoking, chat chewing, family history of alcohol use, missing ART medication, mental distress, low CD4 count, and low income 
were some of the associated factors with AUD in people with HIV AIDS in Africa. Therefore, service delivery to HIV/AIDS patients should primarily focus on early detection and integrated management of AUD and the aforementioned factors.

\section{Abbreviations}

AIDS: Acquired Immune Deficiency Syndrome; AUD: Alcohol Use Disorder; ART: Anti-Retro viral Therapy; Cl: Confidence Interval; HIV: Human Immune-Deficiency Virus; OR: Odds Ratio; PLWHIV: People Living with Human Immune-Deficiency Virus; PRISMA-P: Preferred Reporting Items for Systematic Reviews and Meta-analysis; USA: United States of America; WHO: World Health Organization.

\section{Declarations}

\section{Ethics approval and consent to participate}

Not applicable.

\section{Consent for publication}

Not Applicable

\section{Availability of data and materials}

All data regarding this research work is incorporated in the paper

\section{Competing interests}

No competing interests existed for this work.

\section{Funding}

We authors have no funding source for this review work.

\section{Authors' contributions}

MN conceived and designed this systematic review and meta-analysis. $M N$ and $A B$ developed the search strategy. MN prepared the first draft of manuscript. All authors critically reviewed and approved the final draft of manuscript.

\section{Acknowledgement}

None

\section{Authors information}


Mogesie Necho, Lecturer at Wollo University, College of Medicine and Health Sciences, Dessie, Ethiopia; Email: nechomoges2014@gmail.com

Asmare Belete, Lecturer at Wollo university, College of Medicine and Health Sciences, Department of Psychiatry, Ethiopia; Email: yasmarebel@yahoo.com

Yibeltal Getachew, Lecturer at Diredawa University, College of Medicine and Health Sciences, Department of Psychiatry, Diredawa, Ethiopia; Email:yibeltalgetachew30@gmail.com.

\section{References}

1. Marsano LS, Mendez C, Hill D, Barve S, McClain CJ. Diagnosis and treatment of alcoholic liver disease and its complications. Alcohol Research Health. 2003;27:247-56.

2. Saitz R. Unhealthy alcohol use. N Engl J Med. 2005;352(6):596-607.

3. Organization WH, Unit WHOMoSA. Global status report on alcohol and health, 2014: World Health Organization; 2014.

4. Mathers C, Ayuso-Mateos JL. Global burden of alcohol use disorders in the Year 2000: summary of methods and data sources. Citeseer; 2003.

5. Babor T, Higgins-Biddle J, Saunders J, Monteiro M. AUDIT. The alcohol use disorders identification test. Guidelines for use in primary care. 2nd edn. Geneva: World Health Organization, 2001. 2001.

6. Selnes OA. Impact of HIV infection and alcohol on cognition: a review. Neurobehav Hiv Med. 2010;2:85-94.

7. Duko B, Ayalew M, Ayano G. The prevalence of alcohol use disorders among people living with HIV/AIDS: a systematic review and meta-analysis. Substance abuse treatment, prevention, and policy. 2019;14(1):52.

8. Egbe CO, Dakum PS, Ekong E, Kohrt BA, Minto JG, Ticao CJ. Depression, suicidality, and alcohol use disorder among people living with HIV/AIDS in Nigeria. BMC Public Health. 2017;17(1):542.

9. Farley J, Miller E, Zamani A, Tepper V, Morris C, Oyegunle M, et al. Screening for hazardous alcohol use and depressive symptomatology among HIV-infected patients in Nigeria: prevalence, predictors, and association with adherence. Journal of the International Association of Physicians in AIDS Care. 2010;9(4):218-26.

10. Goar SG, Audu MD, Agbir MT, Dochalson E. Prevalence and socio-demographic correlates of alcohol use disorders among HIV patients. African Journal of Drug and alcohol studies. 2011;10(1).

11. Hahn JA, Cheng DM, Emenyonu NI, Lloyd-Travaglini C, Fatch R, Shade SB, et al Alcohol use and HIV disease progression in an antiretroviral naive cohort. Journal of acquired immune deficiency syndromes (1999). 2018;77(5):492.

12. Martinez P, Andia I, Emenyonu N, Hahn JA, Hauff E, Pepper L, et al. Alcohol use, depressive symptoms and the receipt of antiretroviral therapy in southwest Uganda. AIDS Behav. 2008;12(4):605-12. 
13. Wandera B, Tumwesigye NM, Nankabirwa JI, Kambugu AD, Parkes-Ratanshi R, Mafigiri DK, et al. Alcohol consumption among HIV-infected persons in a large urban HIV clinic in Kampala Uganda: a constellation of harmful behaviors. PloS one. 2015;10(5).

14. Nakimuli-Mpungu E, Musisi S, Katabira E, Nachega J, Bass J. Prevalence and factors associated with depressive disorders in an HIV + rural patient population in southern Uganda. J Affect Disord. 2011;135(1-3):160-7.

15. Myer L, Smit J, Roux LL, Parker S, Stein DJ, Seedat S. Common mental disorders among HIV-infected individuals in South Africa: prevalence, predictors, and validation of brief psychiatric rating scales. AIDS Patient Care STDs. 2008;22(2):147-58.

16. Morojele NK, Kekwaletswe CT, Nkosi S. Associations between alcohol use, other psychosocial factors, structural factors and antiretroviral therapy (ART) adherence among South African ART recipients. AIDS Behav. 2014;18(3):519-24.

17. Cichowitz C, Maraba N, Hamilton R, Charalambous S, Hoffmann CJ. Depression and alcohol use disorder at antiretroviral therapy initiation led to disengagement from care in South Africa. PloS one. 2017;12(12).

18. Cerutti B, Broers B, Masetsibi M, Faturiyele O, Toti-Mokoteli L, Motlatsi M, et al. Alcohol use and depression: link with adherence and viral suppression in adult patients on antiretroviral therapy in rural Lesotho, Southern Africa: a cross-sectional study. BMC Public Health. 2016;16(1):947.

19. Kiunyu R, Obondo A, Kuria M, Mathai M, Gachuno O. PREVALENCE OF ALCOHOL \& SUBSTANCE USE DISORDERS AMONG HIV INFECTED YOUTH AGED BETWEEN 15-25 YEARS AT MBAGATHI HOSPITAL.

20. Kibera AW, Kuria MW, Kokonya DA. Alcohol Use Disorders Among HIV and AIDS Patients at Kenyatta National Hospital (KNH) Comprehensive Care Centre, Nairobi, Kenya. 2017.

21. Medley A, Seth P, Pathak S, Howard AA, DeLuca N, Matiko E, et al. Alcohol use and its association with HIV risk behaviors among a cohort of patients attending HIV clinical care in Tanzania, Kenya, and Namibia. AIDS care. 2014;26(10):1288-97.

22. Seth P, Kidder D, Pals S, Parent J, Mbatia R, Chesang K, et al. Psychosocial functioning and depressive symptoms among HIV-positive persons receiving care and treatment in Kenya, Namibia, and Tanzania. Prev Sci. 2014;15(3):318-28.

23. Chishinga N, Kinyanda E, Weiss HA, Patel V, Ayles H, Seedat S. Validation of brief screening tools for depressive and alcohol use disorders among TB and HIV patients in primary care in Zambia. BMC Psychiatry. 2011;11(1):75.

24. Madhombiro M, Dube B, Dube M, Zunza M, Chibanda D, Rusakaniko S, et al. Intervention for alcohol use disorders at an HIV care clinic in Harare: a pilot and feasibility study. Addiction science clinical practice. 2019;14(1):16.

25. Soboka M, Tesfaye M, Feyissa GT, Hanlon C. Khat use in people living with HIV: a facility-based cross-sectional survey from South West Ethiopia. BMC Psychiatry. 2015;15:69. 
26. Duko B, Gebeyehu A, Ayano G. Prevalence and correlates of depression and anxiety among patients with tuberculosis at WolaitaSodo University Hospital and Sodo Health Center, WolaitaSodo, South Ethiopia, Cross sectional study. BMC Psychiatry. 2015;15:214.

27. Bultum JA, Yigzaw N, Demeke W, Alemayehu M. Alcohol use disorder and associated factors among human immunodeficiency virus infected patients attending antiretroviral therapy clinic at Bishoftu General Hospital, Oromiya region, Ethiopia. PloS one. 2018;13(3).

28. Segni M, Getu T, Demissie H. Substance use and associated factors among retroviral infected (RVI) patients on antiretroviral treatment (ART) at Assela Teaching Hospital. Journal of AIDS and Clinical Research. 2017;8(6).

29. Ayano G, Yohannis K, Abraha M, Duko B. The epidemiology of alcohol consumption in Ethiopia: a systematic review and meta-analysis. Substance abuse treatment, prevention, and policy. 2019;14(1):26.

30. Alem A, Kebede D, Kullgren G. The epidemiology of problem drinking in Butajira, Ethiopia. Acta Psychiatr Scand. 1999;100:77-83.

31. Pengpid S, Peltzer K, Heever HVd. Prevalence of alcohol use and associated factors in urban hospital outpatients in South Africa. Int J Environ Res Public Health. 2011;8(7):2629-39.

32. Sher KJ, Grekin ER, Williams NA. The development of alcohol use disorders. Annu Rev Clin Psychol. 2005;1:493-523.

33. Bryant KJ, Nelson S, Braithwaite RS, Roach D. Integrating HIV/AIDS and alcohol research. Alcohol Res Health. 2010;33(3):167.

34. Achola J, Ghee A, Kihara A. High HIV prevalence, low condom use and gender differences in sexual behavior among patients with STD-related complaints at a Nairobi primary health care clinic. Int $J$ STD AIDS. 1997;8:506-14.

35. Meyerhoff DJ. Effects of alcohol and HIV infection on the central nervous system. Alcohol research Health. 2001;25(4):288-98.

36. Petry NM. Alcohol use in HIV patients: what we don't know may hurt us. Int J STD AIDS. 1999;10(9):561-70.

37. Braithwaite RS, Bryant KJ. Influence of alcohol consumption on adherence to and toxicity of antiretroviral therapy and survival. Alcohol Res Health. 2010;33(3):280.

38. Samet JH, Horton NJ, Traphagen ET, Lyon SM, Freedberg KA. Alcohol consumption and HIV disease progression: are they related? Alcoholism. Clinical Experimental Research. 2003;27(5):862-7.

39. Kumar R, Perez-Casanova AE, Tirado G, Noel RJ, Torres C, Rodriguez I, et al. Increased viral replication in simian immunodeficiency virus/simian-HIV-infected macaques with self-administering model of chronic alcohol consumption. JAIDS Journal of Acquired Immune Deficiency Syndromes. 2005;39(4):386-90.

40. Neuman MG, Schneider M, Nanau RM, Parry C. Alcohol consumption, progression of disease and other comorbidities, and responses to antiretroviral medication in people living with HIV. AIDS research and treatment. 2012;2012. 
41. Wilcox R. Alcohol. and HIV: A serious cocktail for transmission and medication adherence. HIV clinician. 2009;21(1):1-4.

42. Baum MK, Rafie C, Lai S, Sales S, Page JB, Campa A. Alcohol use accelerates HIV disease progression. AIDS Res Hum Retroviruses. 2010;26(5):511-8.

43. Chander G, Lau B, Moore RD. Hazardous alcohol use: a risk factor for non-adherence and lack of suppression in HIV infection. Journal of acquired immune deficiency syndromes (1999). 2006;43(4):411.

44. Abaynew Y, Deribew A, Deribe K. Factors associated with late presentation to HIV/AIDS care in South Wollo ZoneEthiopia: a case-control study. AIDS research therapy. 2011;8(1):8.

45. Pandrea I, Happel KI, Amedee AM, Bagby GJ, Nelson S. Alcohol's role in HIV transmission and disease progression. Alcohol Res Health. 2010;33(3):203.

46. Krupitsky EM, Horton NJ, Williams EC, Lioznov D, Kuznetsova M, Zvartau E, et al. Alcohol use and HIV risk behaviors among HIV-infected hospitalized patients in St. Petersburg, Russia. Drug Alcohol Depend. 2005;79(2):251-6.

47. Kalichman SC, Simbayi LC, Kaufman M, Cain D, Jooste S. Alcohol use and sexual risks for HIV/AIDS in sub-Saharan Africa: systematic review of empirical findings. Prevention science. 2007;8(2):141.

48. Braithwaite R, Conigliaro J, Roberts M, Shechter S, Schaefer A, McGinnis K, et al. Estimating the impact of alcohol consumption on survival for HIV + individuals. AIDS care. 2007;19(4):459-66.

49. Moher D, Shamseer L, Clarke M, Ghersi D, Liberati A, Petticrew M, et al. Preferred reporting items for systematic review and meta-analysis protocols (PRISMA-P) 2015 statement. Systematic reviews. 2015;4(1):1.

50. Stang A. Critical evaluation of the Newcastle-Ottawa scale for the assessment of the quality of nonrandomized studies in meta-analyses. Eur J Epidemiol. 2010;25(9):603-5.

51. Berkey CS, Hoaglin DC, Mosteller F, Colditz GA. A random-effects regression model for meta-analysis. Statistics in medicine. 1995;14(4):395-411.

52. Doi SA, Thalib L. A quality-effects model for meta-analysis. Epidemiology. 2008:94-100.

53. Higgins JP, Thompson SG. Quantifying heterogeneity in a meta-analysis. Statistics in medicine. 2002;21(11):1539-58.

54. Barendregt JJ, Doi SA. MetaXL user guide. Version. 2016;4:2011-6.

55. Nyaga VN, Arbyn M, Aerts M. Metaprop: a Stata command to perform meta-analysis of binomial data. Archives of Public Health. 2014;72(1):39.

56. Liu JL. The role of the funnel plot in detecting publication and related biases in meta-analysis. EvidBased Dent. 2011;12(4):121.

57. Gebre BB. Factors Associated With Alcohol Use Disorder Among People Living With HIV/AIDS Attending Art Clinic, Mizan Tep University Teaching Hospital, South West Ethiopia. HIV/AIDS (Auckland, NZ). 2019;11:239. 
58. Nouaman MN, Vinikoor M, Seydi M, Ekouevi DK, Coffie PA, Mulenga L, et al. High prevalence of binge drinking among people living with HIV in four African countries. J Int AIDS Soc. 2018;21(12):e25202.

59. Soboka M, Tesfaye M, Feyissa GT, Hanlon C. Alcohol use disorders and associated factors among people living with HIV who are attending services in south west Ethiopia. BMC Res Notes. 2014;7(1):828.

60. Tang A, Hamunime N, Adams R, Kanyinga G, Fischer-Walker C, Agolory S, et al. Introduction of an Alcohol-Related Electronic Screening and Brief Intervention (eSBI) Program to Reduce Hazardous Alcohol Consumption in Namibia's Antiretroviral Treatment (ART) Program. AIDS Behav. 2019;23(11):3078-92.

61. Duko B, Toma A, Abraham Y. Alcohol use disorder and associated factors among individuals living with HIV in Hawassa City, Ethiopia: a facility based cross-sectional study. Substance abuse treatment, prevention, and policy. 2019;14(1):22.

62. Urban NB, Kegeles LS, Slifstein M, Xu X, Martinez D, Sakr E, et al. Sex differences in striatal dopamine release in young adults after oral alcohol challenge: a positron emission tomography imaging study with [11C] raclopride. Biol Psychiatry. 2010;68(8):689-96.

63. Peralta RL. "Alcohol allows you to not be yourself": Toward a structured understanding of alcohol use and gender difference among gay, lesbian, and heterosexual youth. Journal of Drug Issues. 2008;38(2):373-99.

64. Amberbir A, Woldemichael K, Getachew S, Girma B, Deribe K. Predictors of adherence to antiretroviral therapy among HIV-infected persons: a prospective study in Southwest Ethiopia. BMC Public Health. 2008;8(1):265.

65. Adams S. Psychopharmacology of tobacco and alcohol comorbidity: a review of current evidence. Current addiction reports. 2017;4(1):25-34.

\section{Tables}

Table 1: Characteristics of studies on alcohol use disorders among HIV/AIDS patients on ART which are incorporated in the narrative as well as meta-analysis according to author first name, year of publication, setting of study, design, sample size, assessment instrument, study population and magnitude of alcohol use disorder. 


\begin{tabular}{|c|c|c|c|c|c|c|c|c|c|c|}
\hline Ir, year & $\begin{array}{l}\text { Study } \\
\text { setting }\end{array}$ & $\begin{array}{l}\text { Study } \\
\text { design }\end{array}$ & $\begin{array}{l}\text { Sample } \\
\text { size }\end{array}$ & $\begin{array}{l}\text { Assessment } \\
\text { tool }\end{array}$ & $\begin{array}{c}\text { Study } \\
\text { population }\end{array}$ & $\begin{array}{l}\text { AUD } \\
(\%)\end{array}$ & $\begin{array}{l}\text { Number of cases } \\
\text { with AUD (n) }\end{array}$ & $\begin{array}{l}\text { Hazardous } \\
\text { Drinker } \\
(\%)\end{array}$ & $\begin{array}{l}\text { Harmful } \\
\text { Drinker } \\
(\%)\end{array}$ & $\begin{array}{l}\text { Dependent } \\
\text { drinker } \\
(\%)\end{array}$ \\
\hline $\begin{array}{l}\text { sa et } \\
.4(1)\end{array}$ & Ethiopia & CS & 401 & AUDIT & $\begin{array}{l}\text { HIV/AIDS } \\
\text { patients }\end{array}$ & 32.6 & 127 & $24.7(96)$ & 2.8 & $5.1(20)$ \\
\hline $\begin{array}{l}\text { et } \\
.7(2)\end{array}$ & Nigeria & CS & 1187 & CIDI & $\begin{array}{l}\text { HIV/AIDS } \\
\text { patients }\end{array}$ & 17 & 202 & 7.0 & 7.8 & 2.2 \\
\hline $\begin{array}{l}\text { et } \\
.1(3)\end{array}$ & Nigeria & CS & 160 & AUDIT & $\begin{array}{l}\text { HIV/AIDS } \\
\text { patients }\end{array}$ & 39.4 & 63 & $10.6 \%$ & 28.8 & 0 \\
\hline $\begin{array}{l}\text { y et al. } \\
4)\end{array}$ & Nigeria & CS & 222 & AUDIT & $\begin{array}{l}\text { HIV/AIDS } \\
\text { patients }\end{array}$ & 12 & 47 & NA & NA & NA \\
\hline $\begin{array}{l}\mathrm{m} \text { et } \\
.8(5)\end{array}$ & Ethiopia & CS & 527 & AUDIT & $\begin{array}{l}\text { HIV/AIDS } \\
\text { patients }\end{array}$ & 14.2 & 75 & 10.8 & 2.5 & 0.8 \\
\hline $\begin{array}{l}\text { et } \\
.9(6)\end{array}$ & Ethiopia & CS & 195 & AUDIT & $\begin{array}{l}\text { HIV/AIDS } \\
\text { patients }\end{array}$ & 31.8 & 62 & NA & NA & NA \\
\hline $\begin{array}{l}\text { et } \\
.7(7)\end{array}$ & Ethiopia & CS & 418 & AUDIT & $\begin{array}{l}\text { HIV/AIDS } \\
\text { patients }\end{array}$ & 24.8 & 104 & NA & NA & NA \\
\hline ..2019(8) & Ethiopia & CS & 332 & AUDIT & $\begin{array}{l}\text { HIV/AIDS } \\
\text { patients }\end{array}$ & 18.4 & 62 & 11.4 & 1.8 & 0.9 \\
\hline $\begin{array}{l}\text { et } \\
.8(9)\end{array}$ & Uganda & Cohort & 446 & AUDIT & $\begin{array}{l}\text { HIV/AIDS } \\
\text { patients }\end{array}$ & 30 & 133 & NA & NA & NA \\
\hline $\begin{array}{l}\text { era et } \\
.5(10)\end{array}$ & Uganda & CS & 725 & AUDIT & $\begin{array}{l}\text { HIV/AIDS } \\
\text { patients }\end{array}$ & 33 & 293 & NA & NA & NA \\
\hline $\begin{array}{l}\text { nez et } \\
\text { 8(11) }\end{array}$ & Uganda & CS & 421 & AUDIT & $\begin{array}{l}\text { HIV/AIDS } \\
\text { patients }\end{array}$ & 1.4 & 6 & NA & NA & NA \\
\hline
\end{tabular}

Table 1: Characteristics of studies on alcohol use disorders among HIV/AIDS patients on ART which are incorporated in the narrative as well as meta-analysis according to author first name, year of publication, setting of study, design, sample size, assessment instrument, study population and magnitude of alcohol use disorder(Continued). 


\begin{tabular}{|c|c|c|c|c|c|c|c|c|c|c|}
\hline rr, year & Study setting & $\begin{array}{l}\text { Study } \\
\text { design }\end{array}$ & $\begin{array}{l}\text { Sample } \\
\text { size }\end{array}$ & $\begin{array}{l}\text { Assessment } \\
\text { tool }\end{array}$ & $\begin{array}{c}\text { Study } \\
\text { population }\end{array}$ & $\begin{array}{l}\text { AUD } \\
(\%)\end{array}$ & $\begin{array}{l}\text { Number of } \\
\text { cases with } \\
\text { AUD (n) }\end{array}$ & $\begin{array}{l}\text { Hazardous } \\
\text { Drinker } \\
(\%)\end{array}$ & $\begin{array}{l}\text { Harmful } \\
\text { Drinker } \\
(\%)\end{array}$ & $\begin{array}{l}\text { Dependent } \\
\text { drinker } \\
(\%)\end{array}$ \\
\hline $\begin{array}{l}\text { inga et } \\
.1(12)\end{array}$ & Zambia & CS & 649 & AUDIT & $\begin{array}{l}\text { HIV/AIDS } \\
\text { patients }\end{array}$ & 14.8 & 96 & NA & NA & NA \\
\hline $\begin{array}{l}\text { nuli et } \\
.1(13)\end{array}$ & Uganda & CS & 500 & AUDIT & $\begin{array}{l}\text { HIV/AIDS } \\
\text { patients }\end{array}$ & 2 & 10 & NA & NA & NA \\
\hline $\begin{array}{l}\text { a et al. } \\
14)\end{array}$ & kenya & CS & 272 & AUDIT & $\begin{array}{l}\text { HIV/AIDS } \\
\text { patients }\end{array}$ & 14 & 38 & NA & NA & NA \\
\hline u et & Kenya & CS & 164 & AUDIT & $\begin{array}{l}\text { HIV/AIDS } \\
\text { patients }\end{array}$ & 33 & 54 & 11 & 9.8 & 12.2 \\
\hline $\begin{array}{l}\text { iwit et } \\
.7(16)\end{array}$ & South Africa & Cohort & 136 & NA & $\begin{array}{l}\text { HIV/AIDS } \\
\text { patients }\end{array}$ & 33 & 45 & NA & NA & NA \\
\hline $\begin{array}{l}\text { lti et } \\
.6(17)\end{array}$ & South Africa & CS & 1388 & AUDIT & $\begin{array}{l}\text { HIV/AIDS } \\
\text { patients }\end{array}$ & 6.6 & 93 & NA & NA & 0.3 \\
\hline $\begin{array}{l}\text { et } \\
8(18)\end{array}$ & South Africa & $\mathrm{CS}$ & 465 & AUDIT & $\begin{array}{l}\text { HIV/AIDS } \\
\text { patients }\end{array}$ & 27 & 126 & NA & NA & NA \\
\hline $\begin{array}{l}\text { jele et } \\
4(19)\end{array}$ & South Africa & CS & 303 & AUDIT & $\begin{array}{l}\text { HIV/AIDS } \\
\text { patients }\end{array}$ & 48.5 & 147 & NA & NA & NA \\
\hline $\begin{array}{l}3 y \text { et } \\
.4(20)\end{array}$ & $\begin{array}{l}\text { Namibia, } \\
\text { Kenya, } \\
\text { Tanzania }\end{array}$ & Cohort & 3538 & AUDIT & $\begin{array}{l}\text { HIV/AIDS } \\
\text { patients }\end{array}$ & 15.7 & 184 & NA & NA & NA \\
\hline $\begin{array}{l}\text { et } \\
.9(21)\end{array}$ & Namibia & $\mathrm{CS}$ & 787 & AUDIT & $\begin{array}{l}\text { HIV/AIDS } \\
\text { patients }\end{array}$ & 30 & 237 & NA & NA & NA \\
\hline $\begin{array}{l}\text { et } \\
.4(22)\end{array}$ & $\begin{array}{l}\text { Namibia, } \\
\text { Kenya, } \\
\text { Tanzania }\end{array}$ & cohort & 3538 & AUDIT & $\begin{array}{l}\text { HIV/AIDS } \\
\text { patients }\end{array}$ & 5.4 & 184 & 0.2 & 3.2 & 2 \\
\hline
\end{tabular}

Key: CS: Cross-sectional, AUDIT: Alcohol use disorder identification test, ART: Anti-retroviral therapy, CIDI: Composite International Diagnostic Interview,

Table 2: A subgroup analysis of the prevalence of alcohol use disorder among HIV AIDS patients on ART in Africa with its 95\% confidence interval 


\begin{tabular}{|c|c|c|c|c|c|c|c|}
\hline \multirow[t]{2}{*}{ Subgroup } & & \multirow[t]{2}{*}{ Number of studies } & \multicolumn{2}{|l|}{ Estimates } & \multicolumn{3}{|c|}{ Heterogeneity } \\
\hline & & & Prevalence (\%) & $95 \% \mathrm{CI}$ & $\mathrm{I}^{2}$ & $\mathrm{Q}(\mathrm{DF})$ & P-value \\
\hline \multirow[t]{6}{*}{ Country } & Ethiopia & 5 & 23.36 & $17.53,31.19$ & $98.6 \%$ & $195.17(4)$ & $\mathrm{P}<0.001$ \\
\hline & Nigeria & 3 & 22.8 & $6.83,38.77$ & $99.5 \%$ & $2037.2(2)$ & $\mathrm{P}<0.001$ \\
\hline & Uganda & 4 & 16.61 & $6.86,26.36$ & $99.8 \%$ & $2120(3)$ & $\mathrm{P}<0.001$ \\
\hline & South Africa & 4 & 28.77 & $10.39,47.16$ & 99. $2 \%$ & $1246.23(3)$ & $\mathrm{P}<0.001$ \\
\hline & Kenya,Namibia\& & & & & & & \\
\hline & & 6 & 18.82 & $10.09,27.54$ & $97.8 \%$ & $123.2(5)$ & $\mathrm{P}<0.001$ \\
\hline \multirow[t]{2}{*}{ Study design used } & Cross-sectional & 18 & 22.25 & $17.13,27.37$ & $98.8 \%$ & $921.57(17)$ & $\mathrm{P}<0.001$ \\
\hline & Cohort & 4 & 21.02 & $9.26,32.79$ & $99.6 \%$ & $742.86(3)$ & $\mathrm{P}<0.001$ \\
\hline \multirow[t]{2}{*}{ Sample size studied } & $<450$ & 12 & 26.46 & & $99.2 \%$ & $1242.12(11)$ & $\mathrm{P}<0.001$ \\
\hline & $>450$ & 10 & 16.71 & $10.30,23.12$ & $98.5 \%$ & $735.25(9)$ & $\mathrm{P}<0.001$ \\
\hline \multirow[t]{3}{*}{ Year of publication } & Before 2011 & 3 & 13.47 & $0.20,26.75$ & $96.5 \%$ & $108.32(2)$ & $\mathrm{P}<0.001$ \\
\hline & $2011-2015$ & 8 & 24.93 & $15.10,34.77$ & $97.9 \%$ & $135.8(7)$ & $P<0.001$ \\
\hline & After 2015 & 11 & 22.88 & $17.71,28.25$ & $99.8 \%$ & $2120(10)$ & $P<0.001$ \\
\hline
\end{tabular}

Key; DF: Degree of Freedom, CI: Confidence Interval

Table 3: a sensitivity analysis of the prevalence of alcohol use disorder among HIV AIDS patients on ART in Africa when each indicated studies are removed at a time with its $95 \%$ confidence interval. 


\begin{tabular}{clll}
\hline No & Study excluded & Prevalence of Alcohol use disorder & $95 \%$ Confidence interval \\
\hline 1 & Soboka et al.2014 & $21.53 \%$ & $16.53,26.52$ \\
2 & Egbe et al.2017 & $22.27 \%$ & $17.25,27.29$ \\
3 & Bultum et al & $22.4 \%$ & $17.39,27.41$ \\
4 & Duko et al.2019 & $21.56 \%$ & $16.58,26.55$ \\
5 & Segni et al.2017 & $21.9 \%$ & $16.82,26.97$ \\
6 & Gebrie, 2019 & $22.20 \%$ & $17.02,27.38$ \\
7 & Goar et al.2011 & $21.20 \%$ & $16.31,26.10$ \\
8 & Farley et al.2010 & $22.51 \%$ & $17.54,27.48$ \\
9 & Hahn et al.2018 & $21.65 \%$ & $16.60,26.69$ \\
10 & Wandera et al.2015 & $21.51 \%$ & $16.52,26.49$ \\
11 & Martinez et al.2008 & $23.01 \%$ & $18.07,27.95$ \\
12 & Chishinga et al.2011 & $22.37 \%$ & $17.34,27.40$ \\
13 & Nakimuli et al.2011 & $22.98 \%$ & $18.05,27.91$ \\
14 & Kibera et al.2017 & $22.41 \%$ & $17.43,27.40$ \\
15 & Kiyunyu et al & $21.51 \%$ & $16.53,26.48$ \\
16 & Cichiwoti et al.2017 & $21.51 \%$ & $16.54,26.48$ \\
17 & Cerruti et al.2016 & $22.76 \%$ & $17.94,27.59$ \\
18 & Myer et al.2008 & $21.79 \%$ & $16.71,26.88$ \\
19 & Morojele et al.2014 & $20.77 \%$ & $16.33,25.31$ \\
20 & Medley et al.2014 & $22.33 \%$ & $17.21,27.45$ \\
21 & Tang et al.2019 & $21.65 \%$ & $16.55,26.75$ \\
22 & Seth et al.2014 & $22.82 \%$ & $18.30,27.34$ \\
\hline & & &
\end{tabular}

Table 4: Characteristics of associated factors for alcohol use disorder among HIV AIDS patients in Africa by their Odds ratio, Confidence interval, association strength, author and year of publication. 


\begin{tabular}{|c|c|c|c|c|c|}
\hline Associated factors & Odds ratio(AOR) & $95 \% \mathrm{CI}$ & Strength of association & Author, year of publication & Remark \\
\hline Cigarette smoking & 3.49 & $1.01,12.13$ & Strong and positive & Bultum et al.2018 & \\
\hline Family history of alcohol use & 3.58 & $15.2,8.47$ & Strong and positive & Bultum et al.2018 & \\
\hline Missing ART drugs & 3.05 & $1.30,7.12$ & Strong and positive & Bultum et al.2018 & \\
\hline Being Male & 3.48 & $1.27,9.59$ & Strong, positive & Gebrie, 2019 & \\
\hline CD4 count of $0-200$ & 19.49 & $1.74,218.4$ & Strong and positive & Gebrie, 2019 & \\
\hline Being male & 14.1 & $5.84,33.87$ & Strong and positive & Segni et al.2017 & \\
\hline Family history of substance use & 2.66 & $1.15,6.13$ & Strong and positive & Segni et al.2017 & \\
\hline Missing a dose of HIV medications & 2.04 & $1.67,2.49$ & Strong and positive & Medley et al.2014 & \\
\hline Inconsistent condom use & 1.49 & $1.23,1.79$ & Moderate and positive & Medley et al.2014 & \\
\hline Commercial sex & 1.57 & $1.06,2.32$ & Moderate and positive & Medley et al.2014 & \\
\hline
\end{tabular}

Characteristics of associated factors for alcohol use disorder among HIV AIDS patients in Africa by their Odds ratio, Confidence interval, association strength, author and year of publication (continued). 


\begin{tabular}{|c|c|c|c|c|c|}
\hline Associated factors & $\begin{array}{l}\text { Odds } \\
\text { ratio(AOR) }\end{array}$ & $\begin{array}{l}\text { 95\% confidence } \\
\text { interval }\end{array}$ & $\begin{array}{l}\text { Strength of } \\
\text { association }\end{array}$ & $\begin{array}{l}\text { Author, year of } \\
\text { publication }\end{array}$ & Remark \\
\hline Male sex & 2.43 & $1.76,5.76$ & Strong and positive & Duko et a;.2019 & \\
\hline Poor social support & 1.34 & $1.12,6.73$ & weak and positive & Duko et a;.2019 & \\
\hline $\begin{array}{l}\text { Being medication non- } \\
\text { adherent }\end{array}$ & 1.78 & $1.33,6.79$ & Strong and positive & Duko et a;.2019 & \\
\hline Chat chewing & 1.67 & $1.16,5.45$ & Strong and positive & Duko et a;.2019 & \\
\hline Cigarette smoking & 3.76 & $2.16,7.54$ & Strong and positive & Duko et a;.2019 & \\
\hline Male sex & $X^{2}=17.999$ & $\mathrm{P}=0.000$ & Strong and positive & Goar et al.2011 & \\
\hline Lower education & $X^{2}=9.86$ & $\mathrm{P}=0.000$ & Strong and positive & Goar et al.2011 & \\
\hline low income & $X^{2}=13.68$ & $\mathrm{P}=0.002$ & Strong and positive & Goar et al.2011 & \\
\hline Male sex & 5.2 & $2.48,11.22$ & Strong and positive & Farley et al.2010 & \\
\hline Orthodox religion & 2.3 & $1.22,4.31$ & Strong and positive & Soboka et al.2016 & \\
\hline Protestant religion & 2.3 & $1.23,4.34$ & Strong and positive & Soboka et al.2016 & \\
\hline Male sex & 2.23 & $1.30,3.83$ & Strong and positive & Soboka et al.2016 & \\
\hline Cigarette smoking & 3.4 & $1.38-8.40$ & Strong and positive & Soboka et al.2016 & \\
\hline Mental distress & 2.24 & $1.40,3.64$ & Strong and positive & Soboka et al.2016 & \\
\hline Being female & 0.1 & $0.05,0.19$ & Strong and negative & Egbe et al. 2017 & $\begin{array}{l}\text { Harmful alcohol } \\
\text { use }\end{array}$ \\
\hline Being Christian & 3.44 & $1.43,8.27$ & Strong and positive & Egbe et al. 2017 & $\begin{array}{l}\text { Harmful alcohol } \\
\text { use }\end{array}$ \\
\hline Being female & 0.32 & $0.13,0.76$ & Strong and negative & Egbe et al. 2017 & $\begin{array}{l}\text { Dependent } \\
\text { drinking }\end{array}$ \\
\hline
\end{tabular}

\section{Additional File Legends}

Additional file 1: A table showing the quality assesment result of included studies.

\section{Figures}



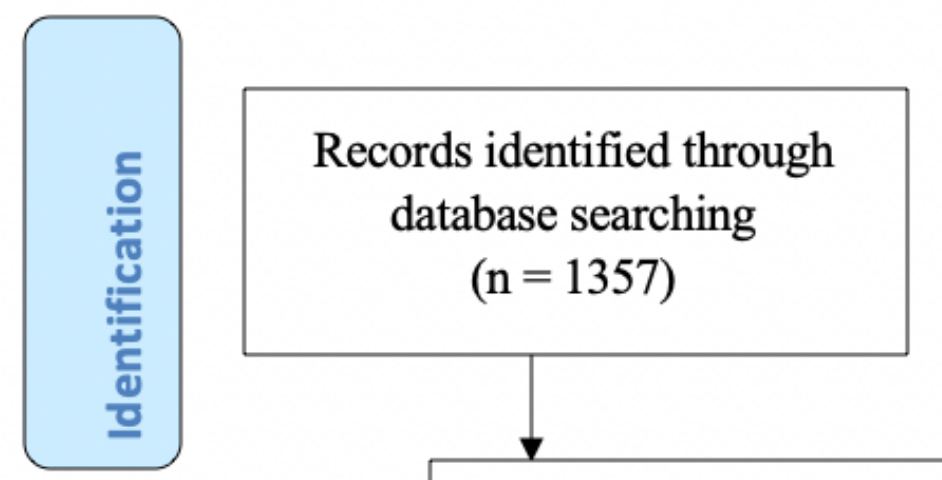

Additional records identified through other sources

$$
(\mathrm{n}=5)
$$

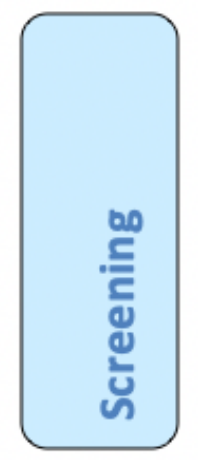

Duplicates removed

$(\mathrm{n}=28)$

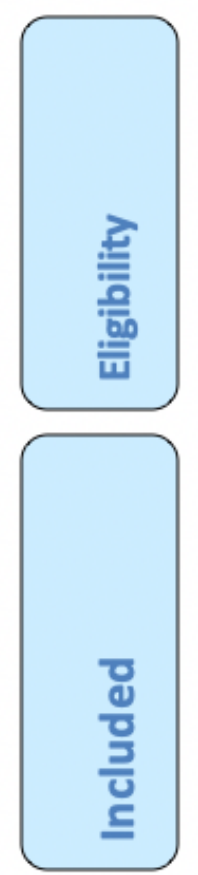

Full text articles assessed for eligibility ( $n=62$ )

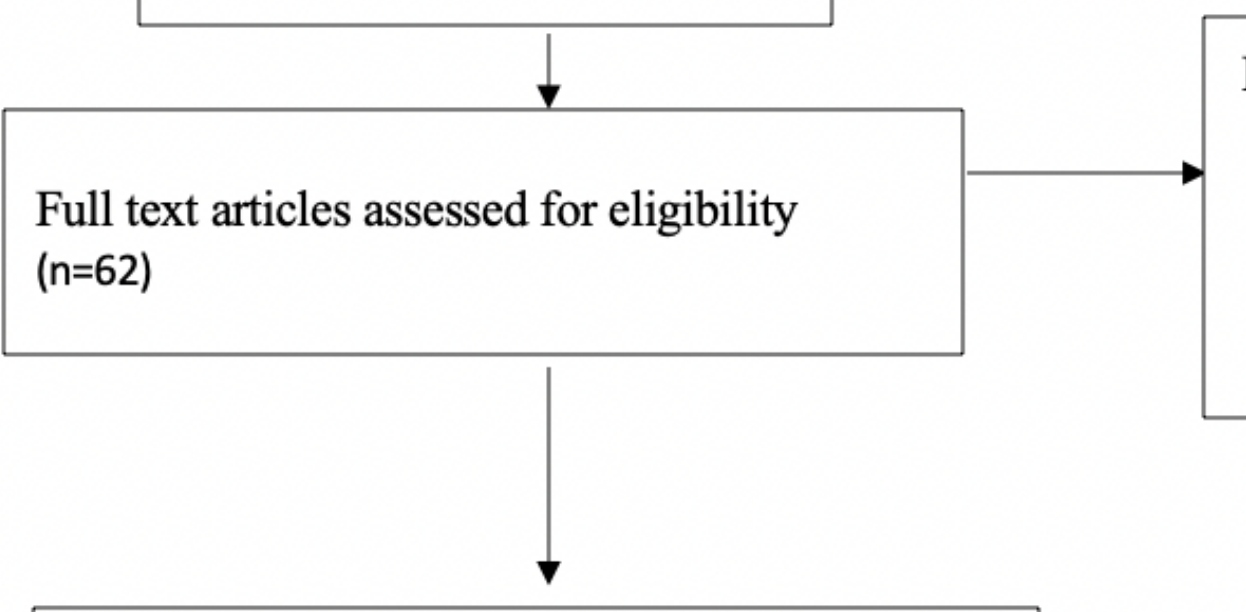

Records excluded

$(n=1272)$

$$
(n=1334)
$$

Full-text articles excluded with reasons $(\mathrm{n}=40)$

Studies included in qualitative and quantitative synthesis

$$
(n=22)
$$

Figure 1

PRISMA flow chart for the review search process 


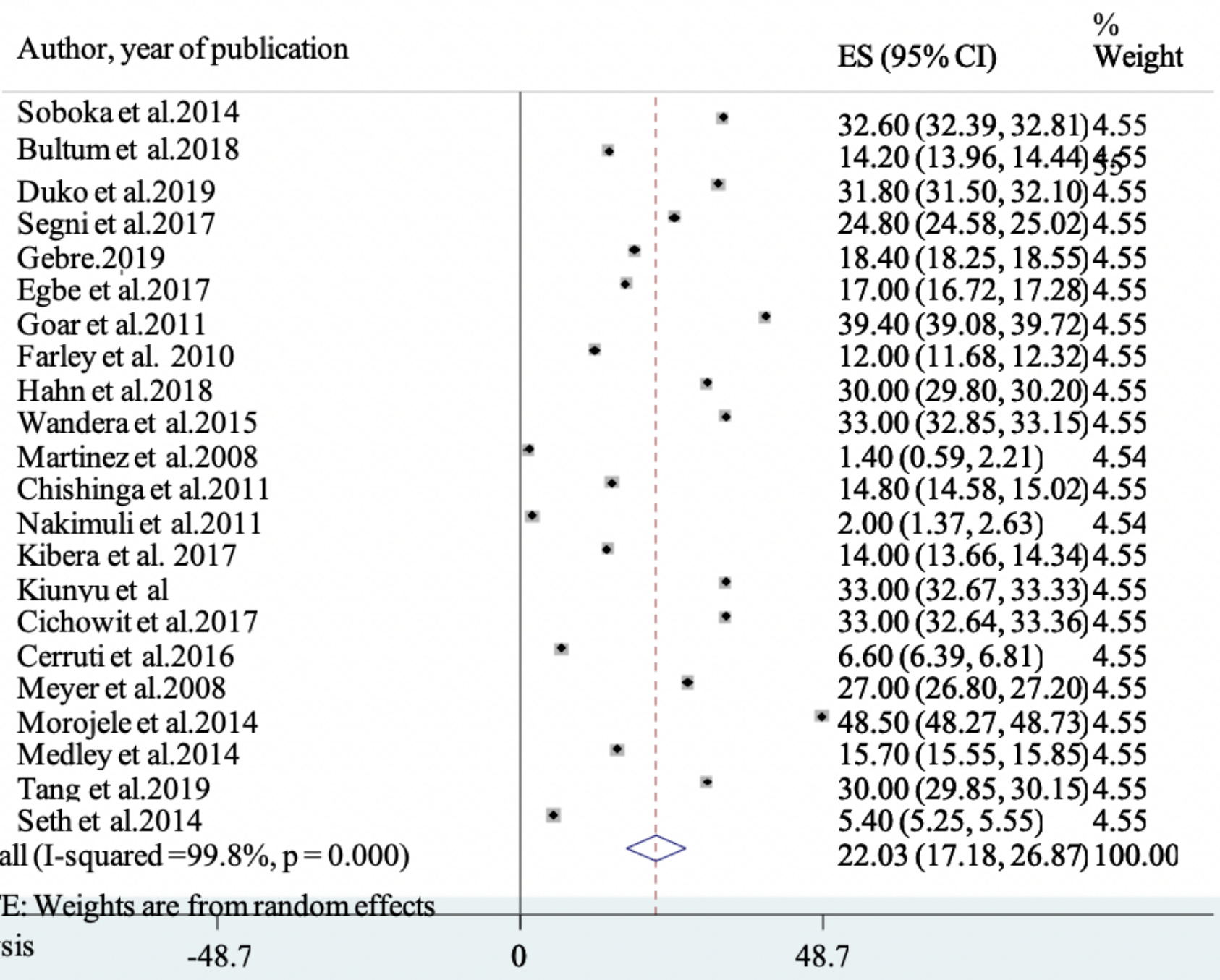

Figure 2

A forest plot for the prevalence of AUD among HIV patient in Africa 


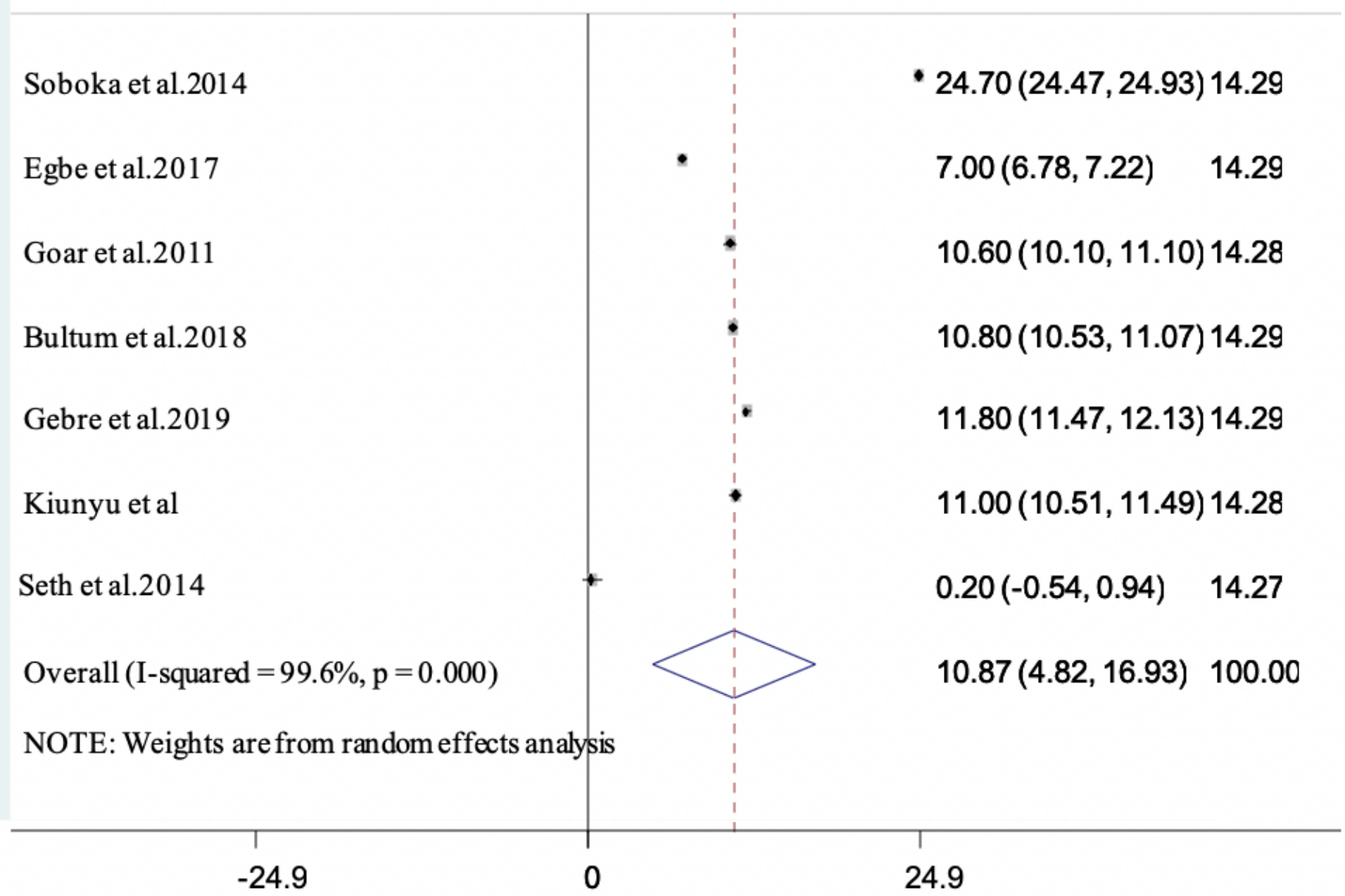

Figure 3

A forest plot for hazardous alcohol use among HIV patients 
Author, year of publication

$$
\mathrm{ES}(95 \% \mathrm{CI}) \quad \% \text { Weigh1 }
$$

Soboka et al.2014

Egbe et al.2017

Goar et al.2011

Bultum et al.2018

Gebre.2019

Kiunyu et al

Seth et al.2014

Overall (I-squared $=99.5 \%, \mathrm{p}=0.000)$

NOTE: Weights are from random effects analysis
$2.80(2.20,3.40) \quad 14.28$

$7.80(7.59,8.01) \quad 14.29$

• $28.80(28.46,29.14) 4.29$

$2.50(1.95,3.05) \quad 14.28$

$1.80(0.99,2.61) \quad 14.27$

$9.80(9.28,10.32) \quad 14.29$

$3.20(3.01,3.39) \quad 14.29$

$8.10(1.04,15.17) \quad 100.00$

Figure 4

A forest plot for harmful alcohol use among HIV patients 
Soboka et al.2014

Egbe et al.2017

Bultum et al.2018

Gebre.2019

Kiunyu et al

Cerruti et al.2016

Seth et al.2014

Overall $(\mathrm{I}$-squared $=99.6 \%, \mathrm{p}=0.000)$

NOTE: Weights are from random effects analysis

\author{
$5.10(4.65,5.55) \quad 14.35$ \\ $2.20(1.81,2.59) \quad 14.36$ \\ $0.80(-0.18,1.78) \quad 14.23$ \\ $0.90(-0.24,2.04) \quad 14.17$ \\ $12.20(11.73,12.67) 4.35$ \\ $0.30(-0.68,1.28) \quad 14.23$ \\ $0.30(-0.29,0.89) \quad 14.32$ \\ $3.12(-0.45,6.70) \quad 100.00$
}

Figure 5

A forest plot for dependent alcohol use among HIV patients 


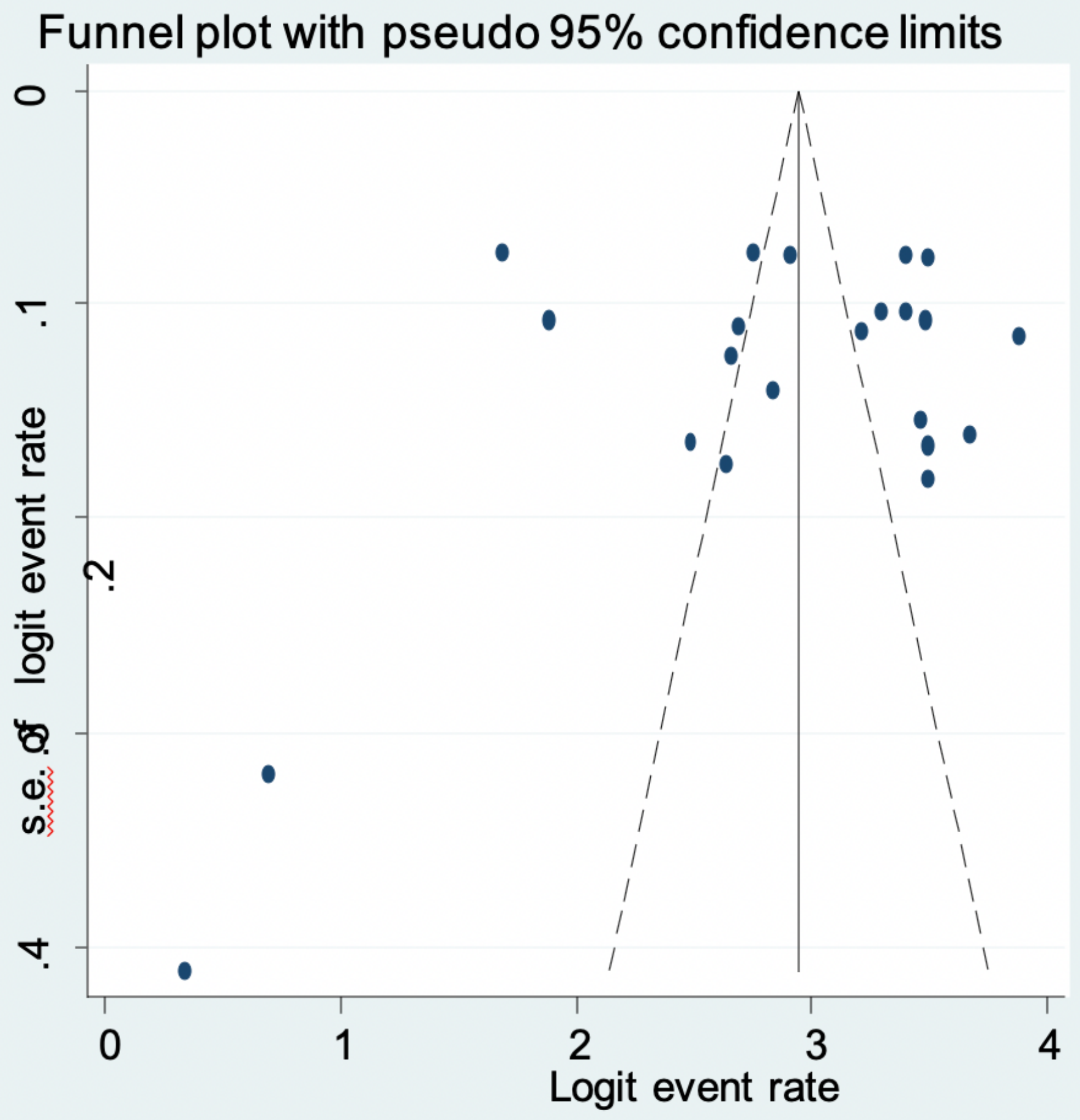

Figure 6

A funnel plot of publication bias for alcohol use disorder

\section{Supplementary Files}

This is a list of supplementary files associated with this preprint. Click to download. 
- Additionalfile1.docx

Page $30 / 30$ 